\title{
PENGARUH KONSENTRASI PUTIH TELUR TERHADAP SIFAT FISIK, KADAR ANTOSIANIN DAN AKTIVITAS ANTIOKSIDAN BUBUK INSTAN EKSTRAK KULIT MANGGIS (Garcinia mangostana L.) DENGAN METODE FOAM MAT DRYING
}

\author{
Bambang Haryanto \\ Widyaiswara Balai Pelatihan Pertanian (BPP) Lampung \\ Email : bambang_haryanto000@yahoo.com
}

\begin{abstract}
Effect Concentration of White Egg on Physical, Anthocyanins Levels and Activities Antioxidant Instant Powder Extract Mangosteen Skin (Garcinia mangostana L.) with Foam Mat Drying. Mangosteen (Garcinia mangostana L.) is a fruit which has many benefits for healthy comparing other fruits. A part of mangosteen skin contains antosianin can be benefit as natural coloring and has a role as antioksidan activity instant powder mangosteen skin and get the best consentration egg white as foam agent result instant powder with foam mat drying method. The result of this research shows that egg white consentration as foam agent gives real influence toward rendemen, antioksidant activity, brightness degree and redness degree of instant powder mangosteen skin extract. Egg white concentration as foam agent which result the best instant powder mangosteen skin gets in concentration egg ehile treatment $15 \%$ with rendemen is $20,48 \%$ miscible degree is $73,39 \%$, soluble speed is 0,00055 / second antosianin content is $2,12 \%$, antioksidan activity is $56.00 \%$, brightness degree $\left(\mathrm{L}^{*}\right)$ is $56,33 \%$ and redness degree $\left(\mathrm{a}^{*}\right)$ is 17,83
\end{abstract}

Keywords: Mangosteen skin, Anthocyanins, Foam mat drying

\begin{abstract}
Abstrak: Pengaruh Konsentrasi Putih Telur terhadap Sifat Fisik, Kadar Antosianin dan Aktivitas Antioksidan Bubuk Instan Ekstrak Kulit Manggis (Garcinia mangostana L.) dengan Metode Foam Mat Drying. Buah manggis (Garcinia mangostana L.) merupakan buah yang mempunyai banyak manfaat bagi kesehatan dibanding buah lainnya. Bagian kulit buah manggis yang mengandung antosianin dapat dimanfaatkan sebagai pewarna alami dan berperan sebagai antioksidan. Penelitian ini bertujuan untuk mengetahui pengaruh konsentrasi putih telur terhadap sifat fisik, kadar antosianin dan aktivitas antioksidan bubuk instan kulit manggis dan mendapatkan konsentrasi putih telur terbaik sebagai foam agent yang menghasilkan bubuk instan dengan metode foam mat drying. Hasil penelitian menunjukkan bahwa konsentrasi putih telur sebagai foam agent memberikan pengaruh nyata terhadap rendemen, aktivitas antioksidan, derajat kecerahan dan derajat kemerahan bubuk instan ekstrak kulit manggis. Konsentrasi putih telur sebagai foam agent yang menghasilkan bubuk instan kulit manggis terbaik diperoleh pada perlakuan konsentrasi putih telur $15 \%$ dengan rendemen sebesar 20,48\%, tingkat kelarutan sebesar 73,39\%, kecepatan larut sebesar 0,0055/detik, kadar antosianin sebesar 2,12\%, aktivitas antioksidan sebesar $56,00 \%$, derajat kecerahan $\left(\mathrm{L}^{*}\right)$ sebesar 56,33 , serta derajat kemerahan $\left(\mathrm{a}^{*}\right)$ sebesar 17,83 .
\end{abstract}

Kata kunci: Kulit manggis, Antosianin, Foam mat drying.

Tanaman manggis (Garcinia mangostana L) merupakan salah satu buah asli negara tropika yang mempunyai prospek cerah untuk dikembangkan di berbagai daerah dengan ekologi yang cocok untuk pertumbuhan manggis.

Buah manggis merupakan buah yang mempunyai banyak manfaat bagi kesehatan dibandingkan buah lainnya. Bagian kulit buah manggis dapat dimanfaatkan sebagai penghasil zat warna alami yang dapat digunakan sebagai pewarna makanan, juga dimanfaatkan sebagai antioksidan.
Kulit buah manggis mengandung antosianin seperti cyanidin-3-sophoroside dan cyanidin-3-glucoside yang merupakan antioksidan dan berperan penting pada pewarnaan kulit manggis, selain itu kulit buahnya mengandung senyawa pektin, tanin, dan resin yang dimanfaatkan untuk menyamak kulit dan sebagai zat pewarna hitam untuk makanan dan industri tekstil, sedangkan getah kuning dimanfaatkan sebagai bahan baku cat dan insektisida (Qosim, 2007). 
Antosianin merupakan salah satu zat pewarna alami berwarna kemerah-merahan yang larut dalam air dan tersebar luas di dunia tumbuhtumbuhan. Antosianin tergolong senyawa flavonoid yang memiliki fungsi sebagai antioksidan alami (Madhavi, 1996 dalam Nuciferani, 2004).

Antioksidan adalah zat yang dapat menangkal atau mencegah reaksi oksidasi dari radikal bebas (Chang et al. 2002). Oksidasi merupakan suatu reaksi kimia yang mentransfer elektron dari suatu zat ke oksidator.

Produk pangan yang dikehendaki oleh masyarakat modern tidak hanya mempertimbangkan unsur pemenuhan gizi, akan tetapi juga harus praktis, cepat saji, tahan lama dan tidak memerlukan tempat atau ruang penyimpanan yang lebih besar. Oleh karena itu, kecenderungan konsumen saat ini mengarah pada produk siap saji (instan), disamping nilai gizi yang diinginkan. Produk pangan bubuk siap saji (instan) merupakan produk pangan yang berbentuk bubuk, berstruktur remah, mudah dilarutkan dengan air dingin maupun air panas, mudah dalam penyajian, mudah terdispersi dan tidak mengendap di bagian bawah wadah (Desrosier, 1988; Wirakartakusuma et al., 1992).

Permasalahan dalam pembuatan bubuk instan adalah kerusakan akibat proses pengeringan yang umumnya memerlukan suhu pemanasan tinggi (lebih $60^{\circ} \mathrm{C}$ ) sehingga mengakibatkan kerusakan flavour atau terjadi pengendapan pada saat bubuk dilarutkan dalam air. Salah satu metode pengeringan yang digunakan untuk membuat bubuk instan adalah metode foam mat yang merupakan metode pengeringan bahan cair yang sebelumnya dijadikan buih terlebih dahulu dengan penambahan zat pembusa dan zat tahan panas dengan tujuan memperluas permukaan, menurunkan tegangan permukaan, meningkatkan rongga, mengembangkan bahan, mempercepat penguapan air, serta menjaga mutu bahan.

Penelitian ini bertujuan untuk mengetahui pengaruh konsentrasi putih telur terhadap sifat fisik, kadar antosianin dan aktivitas antioksidan bubuk instan kulit manggis (Garcinia mangostana L) dengan metode foam mat drying dan untuk mendapatkan konsentrasi putih telur terbaik sebagai foam agent yang menghasilkan bubuk instan dengan metode foam mat drying.

\section{METODE PENELITIAN}

Penelitian dilaksanakan di Laboratorium Pengolahan Hasil Pertanian, Jurusan Teknologi
Hasil Pertanian Universitas Lampung, Laboratorium Jasa Analisis Universitas Brawijaya Malang dan Politeknik Negeri Lampung. Penelitian dilaksanakan pada bulan Oktober 2015 sampai Januari 2016.

Bahan utama yang digunakan dalam penelitian adalah kulit buah manggis dengan tingkat kematangan 5 yaitu berumur 114 hari yang diperoleh dari Kabupaten Tanggamus Provinsi Lampung dan putih telur. Bahan pembantu yang digunakan adalah dekstrin yang diperoleh dari CV Yona Kimia Bandar Lampung dan air.

Alat-alat yang digunakan dalam penelitian antara lain timbangan analitik dua digit (Mettler PJ 3000), pisau stainless stell kiwi, panci email (merk Bima), kompor gas (merk Rinai), blender (merk Phillips), mixer (merk Phillips), sendok, baskom plastik, loyang alumunium, panci, kain saring (Hero), oven vakum, $\mathrm{pH}$ meter, refraktometer, spektrofotometer dan colorimeter.

Penelitian berupa perlakuan tunggal disusun dalam Rancangan Acak Kelompok Lengkap dengan enam perlakuan dan empat ulangan. Perlakuan tunggal adalah konsentrasi putih telur sebagai foam agen yang terdiri dari 6 taraf yaitu $\mathrm{P}_{0}$ (tanpa putih telur), $\mathrm{P} 1$ (konsentrasi putih telur 5\%), P2 (konsentrasi putih telur 10\%), P3 (konsentrasi putih telur 15\%), P4 (konsentrasi putih telur 20\%) dan P5 (konsentrasi putih telur 25\%). Data dianalisis kesamaan ragam dengan uji Bartlet dan kemenambahan data dengan uji Tukey. Selanjutnya dilakukan analisis ragam untuk mengetahui pengaruh perlakuan. Apabila terdapat pengaruh yang nyata, data dianalisis lebih lanjut dengan uji Beda Nyata Terkecil (BNT) pada taraf nyata $5 \%$.

\section{Pembuatan Serbuk Kulit Manggis}

Proses pembuatan serbuk kulit manggis adalah dengan cara memisahkan daging buah manggis dengan kulit manggis menggunakan pisau stainles sebanyak $20 \mathrm{~kg}$. Selanjutnya kulit buah manggis tersebut dikerok dengan sendok untuk memisahkan daging kulit dengan lapisan luar kulit buah manggis yang keras. Setelah dikerok selanjutnya dilakukan pengecilan ukuran dan dilakukan penghancuran menggunakan cuper selama 3 menit dengan kecepatan tinggi (skala 3). Sehingga diperoleh serbuk kulit manggis sebanyak 2,4 kg dengan kadar air 76,2\%.

\section{Pembuatan Filtrat Kulit Manggis}

Proses pembuatan filtrat kulit manggis dimulai dengan penambahan air sebanyak $300 \%$ 
dari bahan berupa serbuk kulit manggis dan direbus selama 30 menit, selanjutnya disaring sehingga diperoleh filtrat sebesar 50\%. Ampas kulit manggis selanjutnya ditambah air sebanyak $300 \%$ kemudian direbus kembali selama 30 menit sehingga diperoleh filtrat kulit manggis. Filtrat kulit manggis perebusan pertama dan kedua digabung kemudian diendapkan selama 12 jam lalu disaring, hasilnya adalah filtrat kulit manggis yang siap untuk dibuat bubuk ekstrak kulit manggis.

\section{Pembuatan Bubuk Instan Ekstrak Kulit Manggis}

Proses pembuatan bubuk instan ekstrak kulit manggis adalah sebagai berikut: Memisahkan putih telur dan kuning telur, selanjutnya menimbang filtrat kulit buah manggis dan putih telur dengan perbandingan (1) $230 \mathrm{~g}: 0$ $\%$; (2) $230 \mathrm{~g}: 5 \%$; (3) $230 \mathrm{~g}: 10 \%$; (4) $230 \mathrm{~g}$ : $15 \%$; (5) $230 \mathrm{~g}: 20 \%$; dan (6) $230 \mathrm{~g}: 25 \%$ dan menimbang dekstrin sebanyak $10 \%$ dari berat bahan atau sebesar $23 \mathrm{~g}$. Setelah bahan ditimbang sesuai dengan perlakuan selanjutnya mencampur filtrat kulit manggis, dekstrin, dan putih telur dengan menggunakan mixer selama 7 menit. Setelah semua bahan tercampur dan membentuk busa kemudian dituangkan pada loyang dengan ketebalan $3 \mathrm{~mm}$ dan dikeringkan pada oven pada suhu $55^{\circ} \mathrm{C}$ selama 7 jam kemudian dihancurkan dengan blender kering selama 30 detik dan diayak dengan ayakan 60 mesh.

\section{HASIL DAN PEMBAHASAN}

\section{Rendemen}

Berdasarkan tabel 1 rata-rata rendemen bubuk instan kulit manggis dengan penambahan putih telur sebagai foam agent dan uji BNT pada taraf 5\% dapat menunjukkan bahwa rendemen bubuk instan ekstrak kulit manggis tanpa penambahan putih telur berbeda nyata dengan perlakuan penambahan putih telur $10 \%, 15 \%$, $20 \%$, dan $25 \%$.

Rerata rendemen bubuk instan ekstrak kulit manggis berkisar antara 14,90 - 22,40\%. Rendemen bubuk kulit manggis cenderung mengalami peningkatan dengan semakin meningkatnya konsentrasi putih telur yang digunakan. Perlakuan P0 (tanpa penambahan putih telur) menghasilkan rendemen bubuk instan ekstrak kulit manggis sebesar $14,90 \%$ dan berturut- turut menunjukkan peningkatan yaitu pada perlakuan P1 (penambahan putih telur 5\%) dengan rata-rata $17,76 \%$, perlakuan P2 (penambahan putih telur 10\%) dengan rata-rata rendemen sebesar 18,79\%, perlakuan P3 (penambahan putih telur 15\%) dengan rata-rata sebesar 20,48 \%, perlakuan P4 (penambahan putih telur 20\%) dengan rata-rata rendemen sebesar 22,10\% serta perlakuan P5 (penambahan putih telur 25\%) dengan rata-rata rendemen sebesar 22,05\%. Hal ini disebabkan penambahan putih telur dapat meningkatkan total padatan pada bahan sejalan dengan pernyataan Nakai dan Modler (1996) bahwa putih telur mengandung $86,70 \%$ air sehingga sisanya adalah total padatan. Estiasih dan Sofiah (2009) menyatakan bahwa pengolahan tepung menggunakan bahan pembuih atau pembusa akan mempengaruhi jumlah rendemen yang diperoleh karena penggunaan bahan pembentuk buih atau busa menyebabkan total padatan produk meningkat akibatnya rendemen bubuk juga meningkat.

Tabel 1. Rendemen bubuk instan ekstrak kulit manggis

\begin{tabular}{lcc}
\hline Perlakuan & $\begin{array}{c}\text { Rendemen } \\
(\%)\end{array}$ \\
\hline P5 (25\% putih telur) & 22,40 & $\mathrm{c}$ \\
\hline P4 (20\% putih telur) & 22,10 & $\mathrm{c}$ \\
P3 (15\% putih telur) & 20,48 & $\mathrm{bc}$ \\
P2 (10\% putih telur) & 18,79 & $\mathrm{~b}$ \\
P1 (5\% putih telur) & 17,76 & $\mathrm{ab}$ \\
P0 (Tanpa putih telur) & 14,90 & $\mathrm{a}$ \\
\hline
\end{tabular}

\begin{aligned} \hline BNT $5 \% & =2,12 \\$\hline Keterangan : & $\begin{aligned} \text { Angka yang diikuti oleh huruf yang } \\ \text { sama, menunjukkan tidak berbeda } \\ \text { pada taraf nyata 5\% }\end{aligned}\end{aligned}$

\section{Tingkat Kelarutan}

Gambar 1 menunjukkan bahwa perlakuan P0 (tanpa putih telur) dengan rata-rata kelarutan sebesar 65,37\%, perlakuan P1 (penambahan putih telur 5\%) dengan rata-rata kelarutan sebesar $67,46 \%$, perlakuan P2 (penambahan putih telur $10 \%$ ) dengan rata-rata kelarutan sebesar 68,05\%, perlakuan P3 (penambahan putih telur 15\%) dengan rata-rata kelarutan sebesar 73,39\%, perlakuan P4 (penambahan putih telur 20\%) dengan rata-rata kelarutan sebesar 75,16\% serta perlakuan P5 (penambahan putih telur 25\%) dengan rata-rata sebesar $75,52 \%$.

Tidak terlihat pengaruh yang nyata tingkat kelarutan bubuk instan ekstrak kulit manggis akibat penambahan putih telur sebagai foam agent diduga karena protein yang terkandung 
dalam putih telur mengandung komponenkomponen tidak larut yang akan membentuk endapan atau residu yaitu solubility index. Solubility index terjadi karena denaturasi protein putih telur dalam jumlah besar selama proses pengeringan produk. Selain itu menurut Misra (2001), buih putih telur dapat meningkatkan luas permukaan bahan dan produk akhir yang dihasilkan dari foam-mat drying sangat berporipori dan menyerap air tanpa pembentukan aglomerat yang besar. Muchtadi dan Sugiyono (1992) menambahkan, sifat produk minuman bubuk yang penting adalah kelarutannya, disamping warna, aroma, dan cita rasa. Kelarutan produk sangat dipengaruhi oleh porositas partikel di mana bila produk semakin porous (berporipori) maka bahan tersebut akan cepat larut.

Tinggi rendahnya kelarutan bubuk selain dari bahan yang ditambahkan juga akibat peralatan yang digunakan. Kondisi pengeringan yang tidak sempurna dan naiknya suhu udara pengering akan berakibat pada tingginya solubility dari produk yang dihasilkan (Widodo, 2003).

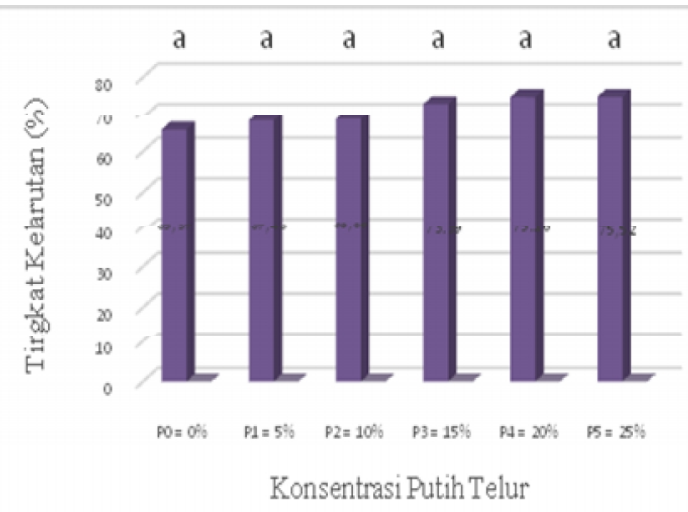

\section{Gambar 1. Kelarutan bubuk instan ekstrak kulit manggis}

\section{Kecepatan Larut}

Bubuk instan ektraks kulit manggis perlakuan P5 (penambahan putih telur 25\%) memiliki kecepatan larut tertinggi sebesar $0.0052 \mathrm{~g}$ /detik, perlakuan P4 (penambahan putih telur $20 \%$ ) sebesar $0,0053 \mathrm{~g} /$ detik, perlakuan P3 (penambahan putih telur 15\%) sebesar 0,0055 g/detik, perlakuan P2 (penambahan putih telur $10 \%$ ) sebesar $0,0056 \mathrm{~g} /$ detik, perlakuan $\mathrm{P} 1$ (penambahan putih telur 5\%) sebesar 0,0061 g/detik.

Gambar 2 menunjukkan bahwa konsentrasi putih telur sebagai foam agent tidak berpengaruh nyata terhadap kecepatan larut bubuk instan kulit manggis. Hal ini diduga putih telur yang digunakan pada berbagai konsentrasi hanya berfungsi sebagai bahan pembusa dengan tujuan untuk mempercepat pengeringan bahan pangan sehingga bahan pangan yang dikeringkan dengan metode foam mat drying mempunyai struktur menyerap air, oleh karena itu bahan pangan tersebut mudah larut dan sekaligus mempengaruhi kecepatan larutnya. Namun terlihat adanya kecenderungan bahwa semakin tinggi konsentrasi putih telur yang ditambahkan, waktu yang dibutuhkan untuk melarutkan bubuk instan kulit manggis lebih lama. Hal ini menunjukkan bahwa penambahan putih telur yang lebih tinggi menyebabkan bubuk instan cepat ringan dan poros sehingga pada waktu diberi air melayang dahulu baru kemudian menyerap air sehingga waktu larutnya lebih lambat. Hasil ini sesuai dengan pendapat Woodrof dan Luh (1975) yang menyatakan bahwa makanan yang dikeringkan dengan metoda pengering busa mempunyai struktur yang lebih porous sehingga bahan pangan tersebut mudah menyerap air akibatnya makanan tersebut mudah dilarutkan dengan air dingin.

Menurut Alfian (2008), faktor-faktor yang mempengaruhi kelarutan adalah $\mathrm{pH}$, temperatur, jenis pelarut, bentuk dan ukuran partikel, konstanta dielekrik pelarut, dan surfaktan, serta efek garam.

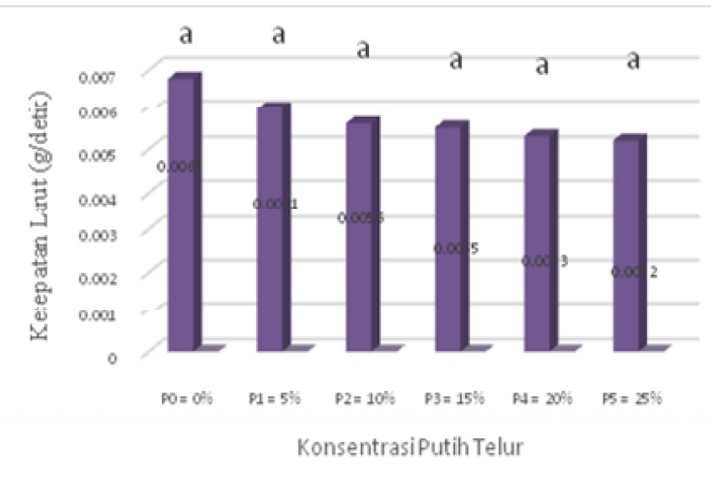

Gambar 2. Kecepatan larut bubuk instan ekstrak kulit manggis

\section{Kadar Antosianin}

Gambar 3 menunjukkan bahwa bubuk instan ekstrak kulit manggis pada perlakuan P5 (penambahan putih telur 25\%) menghasilkan rata-rata kadar antosianin terendah yaitu sebesar $1,78 \mathrm{mg} / \mathrm{l}$, sedangkan pada perlakuan P0 (tanpa penambahan putih telur) menghasilkan rata-rata kadar antosianin tertinggi yaitu sebesar 2,63 $\mathrm{mg} / \mathrm{l}$. Perlakuan P1 (penambahan putih telur 5\%) memberikan rata-rata kadar antosianin sebesar 2,42 mg/l, perlakuan P2 (penambahan putih telur $10 \%)$ sebesar $2,32 \mathrm{mg} / \mathrm{l}$, perlakuan $\mathrm{P} 3$ (penambahan putih telur $15 \%$ ) sebesar $2,12 \mathrm{mg} / 1$ 
serta perlakuan P4 (penambahan putih telur 20\%) sebesar $1,81 \mathrm{mg} / \mathrm{l}$.

Hasil penelitian menunjukkan bahwa penambahan putih telur tidak mempengaruhi kadar antosianin karena putih telur berfungsi sebagai bahan yang digunakan untuk mempercepat pengeringan dan tidak mempengaruhi kadar antosianin. Hasil ini sesuai dengan pendapat Murtala (1999) yang menyatakan bahwa foam mat drying memerlukan bahan pengisi yang berfungsi membentuk foam dan melapisi komponen flavour, mencegah kerusakan akibat panas, meningkatkan total padatan dan rendemen serta mempercepat pengeringan. Putih telur merupakan bahan yang berperan dalam pembentukan foam. Menurut Stadelman dan Cotterill (1977), protein putih telur yang berperan dalam pembentukan buih yaitu ovomucin, globulin serta ovalbumin dimana bahan-bahan tersebut bukan sebagai bahan yang berperan dalam peningkatan kadar antosianin namun hanya sebagai bahan untuk mempercepat pengeringan.

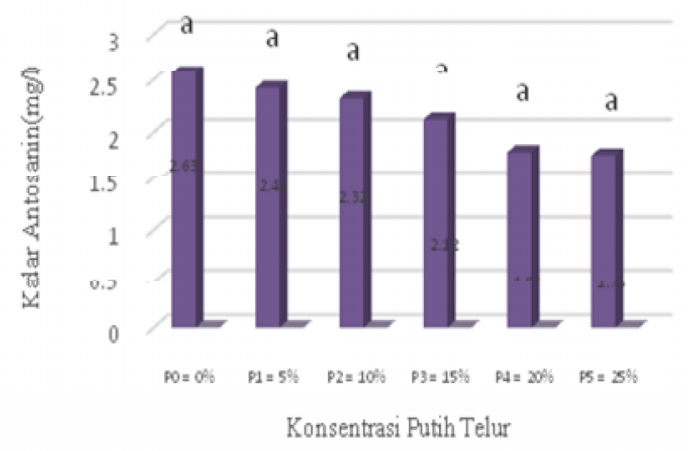

Gambar 3. Kadar antosianin bubuk instan kulit manggis

\section{Aktivitas Antioksidan}

Tabel 2 menunjukkan rerata aktivitas antioksidan bubuk instan ekstrak kulit manggis antara 44,50\% - 66,25\%. Aktivitas antioksidan tertinggi diperoleh pada perlakuan P5 (25\% putih telur) yaitu sebesar $66,25 \%$ dan terendah pada perlakuan P2 (10\% putih telur) dengan aktivitas antioksidan sebesar 44,50\%. Perlakuan P4 (20\% putih telur) memiliki aktivitas antioksidan sebesar $60,50 \%$, perlakuan P3 (15\% putih telur) dengan kapasitas antioksidan $56,00 \%$ dan P1 (5\% putih telur) dengan aktivitas antioksidan sebesar 56,00\%. Hasil ini diduga karena dengan konsentrasi putih telur yang tinggi, terjadinya busa yang lebih banyak sehingga menyebabkan larutan mudah kering, akibatnya aktivitas antioksidan menjadi lebih tinggi. Hasil ini sesuai dengan pendapat $\mathrm{Yu}$ et al. (2007) menyatakan bahwa aktivitas antioksidan alfa mangostin kulit manggis rata-rata sebesar $53,5 \%$. Hasil ini didukung pendapat Rahayuni et al. (2002) yang menyatakan bahwa tingginya aktivitas penangkapan radikal bebas pada bubuk instan bukan karena penambahan putih telur tetapi putih telur berperan sebagai foam agent untuk mempercepat proses pengeringan, sehingga tidak merusak senyawa penting bahan yang dikeringkan.

\begin{tabular}{ll} 
Tabel 2. & $\begin{array}{l}\text { Aktivitas antioksidan bubuk instan } \\
\text { kulit manggis }\end{array}$ \\
\hline Perlakuan & $\begin{array}{l}\text { Aktivitas } \\
\text { antioksidan (\%) }\end{array}$ \\
\hline P5 (25\% putih telur) & $66,25 \mathrm{C}$ \\
P4 (20\% putih telur) & $60,50 \mathrm{Bc}$ \\
P3 (15\% putih telur) & $56,00 \mathrm{~B}$ \\
P1 (5\% putih telur) & $56,00 \mathrm{~B}$ \\
P0 (tanpa putih telur) & $46,00 \mathrm{~A}$ \\
P2 (10\% putih telur) & $44,50 \mathrm{~A}$ \\
\hline BNT 5\% = 8,859
\end{tabular}

Keterangan : angka yang diikuti huruf yang sama tidak berbeda nyata pada taraf nyata $5 \%$.

\section{Derajat Kecerahan $\left(\mathrm{L}^{*}\right)$}

Tabel 3 menunjukkan rerata derajat kecerahan bubuk instan kulit manggis antara 49,85 - 57,30. Derajat kecerahan bubuk instan ekstrak kulit manggis cenderung mengalami peningkatan dengan semakin meningkatnya konsentrasi putih telur yang digunakan. Perlakuan P0 (tanpa penambahan putih telur) menghasilkan derajat kecerahan sebesar 49,85 yang berbeda nyata dengan perlakuan P1 (penambahan putih telur 5\%) sebesar 56,10, perlakuan P2 (penambahan putih telur $10 \%$ ) sebesar 56,15, perlakuan P3 (penambahan putih telur 15\%) sebesar 56,33 perlakuan P4 (penambahan putih telur 20\%) sebesar 57,30 dan perlakuan P5 (penambahan putih telur 25\%) sebesar 55,70. Hasil ini diduga putih telur dapat mempengaruhi tingkat kecerahan bubuk instan kulit manggis, dimana putih telur yang berwarna putih tidak tembus pandang dan mampu menutupi warna asli bubuk instan kulit manggis (kemerahan). Menurut Wilde et al. (1996), ketika putih telur dikocok, gelembunggelembung udara akan bergabung dan berangsurangsur menjadi lebih kecil dan berubah warna dari kemerahan tembus pandang menjadi tidak tembus pandang. Sedangkan Karim dan Wai (1997) menyatakan bahwa konsentrasi putih telur yang lebih tinggi akan melindungi bubuk instan 
dari terjadinya reaksi Maillard akibat perlakuan pemanasan sehingga menyebabkan bubuk instan menjadi lebih cerah.

Tabel 3. Tingkat kecerahan $\left(L^{*}\right)$ bubuk instan kulit manggis

\begin{tabular}{lc}
\hline Perlakuan & $\left(\mathrm{L}^{*}\right)$ \\
\hline P4 (20\% putih telur) & $57,30 \mathrm{~b}$ \\
P3 (15\% putih telur) & $56,33 \mathrm{~b}$ \\
P2 (10\% putih telur) & $56,15 \mathrm{~b}$ \\
P1 (5\% putih telur) & $56,10 \mathrm{~b}$ \\
P5 (25\% putih telur) & $55,70 \mathrm{~b}$ \\
Po (tanpa putih telur) & $49,85 \mathrm{a}$ \\
\hline
\end{tabular}

BNT $5 \%=2,67$

Keterangan : angka yang diikuti huruf yang sama menunjukkan tidak berbeda nyata pada taraf nyata $5 \%$.

\section{Derajat Kemerahan ( $\left.a^{*}\right)$}

Tabel 4 menunjukkan rerata derajat kemerahan bubuk instan ekstrak kulit manggis berkisar antara 17,30 - 19,18. Derajat kemerahan bubuk instan ekstrak kulit manggis cenderung mengalami penurunan dengan semakin meningkatnya konsentrasi putih telur yang digunakan. Derajat kemerahan terendah pada perlakuan P4 ( penambahan putih telur 20\%) sebesar 17,30. Perlakuan P5 (penambahan putih telur 25\%) sebesar 17,68. Perlakuan P3 (penambahan putih telur 15\%) sebesar 17,83 dan derajat kemerahan tertinggi diperoleh pada perlakuan P0 (tanpa putih telur) sebesar 19,18. Bubuk instan ekstrak kulit manggis tanpa penambahan putih telur memiliki derajat kemerahan tertinggi karena bahan penyusun bubuk instan kulit manggis dengan penambahan putih telur dilindungi oleh putih telur sehingga warna bubuk instan tersebut ditutupi. Hal ini diduga bahwa buih putih telur berwarna putih, tidak tembus pandang dan mampu menutupi warna asli bubuk instan kulit manggis (kemerahan). Pada saat pengeringan dengan oven pada suhu $55^{\circ} \mathrm{C}$, panas dari alat akan langsung mengenai bahan sehingga bubuk tanpa penambahan putih telur berwarna kemerahan.

Menurut Karim dan Wai (1997), bahan pangan dalam bentuk cair yang ditambah dengan putih telur akan cepat mengering. Dilaporkan bahwa putih telur yang dibusakan mampu melindungi bahan tersebut dari reaksi Maillard.
Akibatnya derajat kemerahan bubuk instan ekstrak kulit manggis semakin berkurang karena buih putih telur yang tidak tembus pandang menutupi warna bahan tersebut. Reaksi Maillard dalam makanan dapat berfungsi untuk menghasilkan flavour dan aroma, dapat menyebabkan berkurangnya ketersediaan asam amino, kehilangan nilai gizi, pembentukan antinutrisi, pembentukan komponen toksik dan komponen mutagenik.

\section{Tabel 4. Tingkat kemerahan bubuk instan} kulit manggis

\begin{tabular}{lc}
\hline Perlakuan & $\left(\mathrm{a}^{*}\right)$ \\
\hline P0 (Tanpa putih telur & $19,18 \mathrm{~b}$ \\
P1 (5\% putih telur) & $18,30 \mathrm{ab}$ \\
P2 (10\% putih telur) & $17,98 \mathrm{ab}$ \\
P3 (15\% putih telur) & $17,83 \mathrm{a}$ \\
P5 (25\% putih telur) & $17,68 \mathrm{a}$ \\
P4 (20\% putih telur) & $17,30 \mathrm{a}$ \\
\hline BNT 5\%=1,28
\end{tabular}

Keterangan : angka yang diikuti huruf yang sama menunjukkan tidak berbeda nyata pada taraf nyata $5 \%$.

\section{Penentuan Perlakuan Terbaik}

Penentuan perlakuan terbaik dilakukan dengan cara memilih perlakuan yang menghasilkan bubuk instan yang dapat diterima masyarakat. Pada penelitian ini, pemilihan perlakuan terbaik ditetapkan berdasarkan sifat fisik dan sifat kimia bubuk instan ekstrak kulit manggis. Penentuan sifat fisik dilakukan terhadap rendemen, tingkat kelarutan, kecepatan larut, intensitas warna yaitu derajat kecerahan $\left(\mathrm{L}^{*}\right)$ dan derajat kemerahan $\left(\mathrm{a}^{*}\right)$, sedangkan penentuan sifat kimia dilakukan terhadap kadar antosianin dan aktivitas antioksidan. Bubuk instan kulit manggis yang diharapkan adalah memiliki rendemen yang tinggi, tingkat kelarutan tinggi, cepat larut, warna cerah dan derajat kecerahan kemerahan tinggi, kadar antosianin dan aktivitas antioksidan kuat. Perlakuan yang mempunyai bintang terbanyak dengan mempertimbangkan sifat fisik dan sifat kimia dengan kriteria tersebut dipilih sebagai produk terbaik bubuk instan ekstrak kulit manggis dengan metode foam mat drying. Rekapitulasi dari enam perlakuan disajikan pada tabel 5 . 
Tabel 5. Rekapitulasi data bubuk instan kulit manggis.

\begin{tabular}{lcccccc}
\hline PARA-METER & \multicolumn{7}{c}{ PERLAKUAN } \\
\cline { 2 - 7 } & P0 & P1 & P2 & P3 & P4 & P5 \\
\hline Rendemen & 14,90 & 17,76 & 18,79 & $20,48^{*}$ & $22,10^{*}$ & $22,40^{*}$ \\
Tingkat Kelarutan & 65,37 & 67,46 & 68,05 & $73,39^{*}$ & $75,16^{*}$ & $75,52^{*}$ \\
Kecepatan Larut & 0,0068 & 0,0061 & $0,0056^{*}$ & $0,0055^{*}$ & $0,0053^{*}$ & $0,0052^{*}$ \\
Kadar Antosianin & $2,63^{*}$ & $2,42^{*}$ & $2,32^{*}$ & $2,12^{*}$ & 1,81 & 1,78 \\
Aktivitas Antioksin & 46,00 & $56,00^{*}$ & 44,50 & $56,00^{*}$ & $60,50^{*}$ & $66,25^{*}$ \\
Derajat kecerahan & 49,85 & $56,10^{*}$ & 56,15 & $56,33^{*}$ & $57,30^{*}$ & $55,70^{*}$ \\
Derajat kemerahan & $19,18^{*}$ & $18,30^{*}$ & $17,98^{*}$ & 17,83 & 17,30 & 17,68 \\
\hline
\end{tabular}

Keterangan :

Po = Tanpa putih telur

P1 = Konsentrasi putih telur $5 \%$

P2 = Konsentrasi putih telur $10 \%$

Berdasarkan tabel 5, perlakuan terbaik adalah perlakuan P3 (penambahan putih telur 15\%) karena perlakuan ini mempunyai rendemen bubuk instan kulit manggis yang tinggi, tingkat

\section{SIMPULAN}

Berdasarkan hasil penelitian maka dapat disimpulkan sebagai berikut :

1. Konsentrasi putih telur sebagai foam agent berpengaruh nyata terhadap rendemen, aktivitas antioksidan, derajat kecerahan dan derajat kemerahan bubuk instan ekstrak kulit manggis.

2. Konsentrasi putih telur telur sebagai foam agent yang menghasilkan bubuk instan

\section{DAFTAR PUSTAKA}

Alfian, K. 2008. Laporan Praktikum Kelarutan bubuk Instan. Universitas Sumatera Utara.

Chang, L.Y, W. Jhe., S.C. Huang dan Duh., Pir Der. 2002. Antioxidant Activity of Sesame Coat. Journal Food Chemistry. 78:347-354

Desrosier, NW. 1988. Teknologi Pengawetan Pangan. Penterjemah M. Muljoharjo. Jakarta: Penerbit UI-Press; 614 Hal.

Estiasih dan Sofiah. 2009. Pembuatan Tepung dengan Metode Foam Mat Drying. Universitas Muhamadiyah Malang.

Karim, A.A dan Wai, C.C. 1997. Foam mat drying starfruit (Averrhoa carambola L.) purre. Stability and air drying characteristic. Journal Food Chemistry. 64 (1997) hal $337-343$.
P3 = Konsentrasi putih telur 15\%

P4 = Konsentrasi putih telur 20\%

P5 = Konsentrasi putih telur $25 \%$

kelarutan dan kecepatan larut cukup baik, kadar antosianin yang baik, aktivitas antioksidan yang cukup baik, derajat kecerahan dan derajat kemerahan cukup tinggi. ekstrak kulit manggis terbaik diperoleh pada perlakuan konsentrasi putih telur 15\% (P3) dengan rendemen sebesar $20,48 \%$, tingkat kelarutan sebesar 73,39\%, kecepatan larut sebesar 0,0055/detik, kadar antosianin sebasar 2,12\%, kapasitas antioksidan sebesar $56,00 \%$, derajat kecerahan $\left(\mathrm{L}^{*}\right)$ sebesar 56,33 , serta derajat kemerahan $\left(\mathrm{a}^{*}\right)$ sebesar 17,83 .

Muchtadi T.R dan Sugiyono. 1992. Ilmu Pengetahuan Bahan Pangan. Departemen Pendidikan dan Kebudayaan. Direktorat Jenderal Pendidikan Tinggi Pusat Antar Universitas Pangan dan Gizi. IPB Bogor.

Murtala, S. S. 1999. Pengaruh Kombinasi Jenis dan Konsentrasi Bahan Pengisi Terhadap Kualitas Bubuk Sari Buah Markisa Siul (Passiflora edulis F. Edulis). (Tesis) Pasca Sarjana Universitas Brawijaya Malang.

Misra, N. 2001. Process Technology for Tomato Powder.http://www.iitkgp,ernet.in/sric/gett e ch.php? slno=1 Tanggal akses 20 Juni 2012.

Nakai and Modler. 1996. Food Proteins: Properties and Caharacterization. Wiley CVH ISBN 978-0-471-18614-4. 
Nuciferani, N.M. 2004. Potensi Pigmen Antosianin Bunga Mawar (Rosa Sp) Sortiran sebagai Zat Warna dan Antioksidan Alami pada Produk Yoghurt dan Sari Buah Jeruk (Kajian Warna Bunga dan Umur Simpan). (Skripsi) Universitas Muhamadiyah Malang.

Qosim, W.A. 2007. Kulit Buah Manggis Sebagai Antioksidan.

http//anekaplanta.wordpress.com/2007/12/

26/kulit-buah-manggis-

sebagaiantioksidan/. Diakses pada tanggal 31 Maret 2014

Rahayuni K. Y. 2002. Pengeringan dengan metode Foam Mat Drying pada buah tomat. (Skripsi). Universitas Andalas. Sumatera Barat.

Stadelman, W.J and O.J Cotterill. 1977. Egg Science. Publisher Company Inc. Wesport, Connecticut.
Yu, Zhao M, Yang B, Zhao Q, Jiang Y. 2007. Phenolics From Hull of Garcinia mangostana Fruit and Their Antioxidant Activities. Journal Food Chemistry.104(1): 176-181.

Woodroof, L.G., and B.S., Luh. 1975. Commercial Fruit Processing. The AVI Publishing Company, Inc. Wesport, Connecticut.

Widodo. 2003. Bioteknologi Industri Susu. Yogyakarta: Lacticia Press.

Wilde, P.J. and Clark, D.C. 1996. Methods Of Testing Protein Functionality. G.M.Hal, Balckie Academic and Profesional : 111152.

Wirakartakusuma, K. Abdullah, dan A. Syarif. 1992. Sifat Fisik Pangan. Departemen Pendidikan dan Kebudayaan. Direktorat Jenderal Pendidikan Tinggi. Pusat Antar Universitas Pangan dan Gizi. Institut Pertanian Bogor. Bogor. 